NBER WORKING PAPER SERIES

DID FRANCE CAUSE THE GREAT DEPRESSION?

\author{
Douglas A. Irwin \\ Working Paper 16350 \\ http://www.nber.org/papers/w16350 \\ NATIONAL BUREAU OF ECONOMIC RESEARCH \\ 1050 Massachusetts Avenue \\ Cambridge, MA 02138 \\ September 2010
}

I thank Barry Eichengreen, James Feyrer, Nancy Marion, Allan Meltzer, Michael Mussa, Marjorie Rose, Scott Sumner, and Peter Temin for helpful comments and conversations. The views expressed herein are those of the author and do not necessarily reflect the views of the National Bureau of Economic Research.

NBER working papers are circulated for discussion and comment purposes. They have not been peerreviewed or been subject to the review by the NBER Board of Directors that accompanies official NBER publications.

(C) 2010 by Douglas A. Irwin. All rights reserved. Short sections of text, not to exceed two paragraphs, may be quoted without explicit permission provided that full credit, including $\odot$ notice, is given to the source. 
Did France Cause the Great Depression?

Douglas A. Irwin

NBER Working Paper No. 16350

September 2010

JEL No. E31,E42,E5,N14

\begin{abstract}
The gold standard was a key factor behind the Great Depression, but why did it produce such an intense worldwide deflation and associated economic contraction? While the tightening of U.S. monetary policy in 1928 is often blamed for having initiated the downturn, France increased its share of world gold reserves from 7 percent to 27 percent between 1927 and 1932 and effectively sterilized most of this accumulation. This "gold hoarding" created an artificial shortage of reserves and put other countries under enormous deflationary pressure. Counterfactual simulations indicate that world prices would have increased slightly between 1929 and 1933, instead of declining calamitously, if the historical relationship between world gold reserves and world prices had continued. The results indicate that France was somewhat more to blame than the United States for the worldwide deflation of 1929-33. The deflation could have been avoided if central banks had simply maintained their 1928 cover ratios.
\end{abstract}

\author{
Douglas A. Irwin \\ Department of Economics \\ Dartmouth College \\ Hanover, NH 03755 \\ and NBER \\ douglas.irwin@dartmouth.edu
}




\section{Did France Cause the Great Depression?}

\section{Introduction}

A large body of economic research has linked the gold standard to the length and severity of the Great Depression of the 1930s. ${ }^{1}$ The gold standard's fixed-exchange rate regime transmitted financial disturbances across countries and prevented the use of monetary policy to address the economic crisis. This conclusion is supported by two compelling observations: countries not on the gold standard managed to avoid the Great Depression almost entirely, while countries on the gold standard did not begin to recover until after they left it. ${ }^{2}$

While the link between the gold standard and the Great Depression is widely accepted, it begs the question of how the international monetary system produced such a monumental economic catastrophe. Structural flaws in the post-World War I gold standard and the fragility of international financial stability are often blamed for the problems of the period. However, it is not clear why such factors should have necessarily led to the massive price deflation experienced between 1929 and 1933 and the enormous economic difficulties that followed. In particular, there was no apparent shortage of gold in the 1920s and 1930s - worldwide gold reserves continued to expand - so it is not obvious why the system self-destructed and produced such a cataclysm.

${ }^{1}$ See Choudhri and Kochin (1982), Eichengreen and Sachs (1985), Temin (1989), Eichengreen (1992), and Bernanke (1995), among many other works.

${ }^{2}$ In terms of countries that were not on the gold standard, Spain and China stand out as examples. Because countries on the gold standard chose to leave it at different times - the United Kingdom in 1931, the United States in 1933, and France in 1936 - there is sufficient variation in country experiences to identify this relationship. 
To explain the disaster, contemporary observers and economic historians have pointed to the policies followed by central banks. The standard explanation for the onset of the Great Depression is the tightening of U.S. monetary policy in early 1928 (Friedman and Schwartz 1963, Hamilton 1987). The increase in U.S. interest rates attracted gold from the rest of the world, but the gold inflows were sterilized by the Federal Reserve so that they did not affect the monetary base. This forced other countries to tighten their monetary policies as well, without the benefit of a monetary expansion in the United States. From this initial deflationary impulse came currency crises and banking panics that merely reinforced the downward spiral of prices. The United States deserves blame for starting the vicious cycle in the view of many economists. Friedman and Schwartz $(1963,360)$ argue that "the United States was in the van of the movement and not a follower." Similarly, Eichengreen $(1992,222)$ states that "events in America were directly responsible for the slowdown in other parts of the world."

However, what often frequently overlooked - or mentioned only in passing - is the fact that France was doing almost exactly the same thing. In fact, France was accumulating and sterilizing gold reserves at a much more rapid rate than the United States. Contemporary observers then and scholars of the Great Depression today have been aware of this fact, but it still remains a relatively neglected factor whose importance has not been fully appreciated.

Some scholars of French monetary history have even concluded that France deserves more blame than the United States for the world's increasing monetary stringency in the late

3 "The international effects were severe and the transmission rapid, not only because the gold-exchange standard had rendered the international financial system more vulnerable to disturbances, but also because the United States did not follow gold-standard rules," Friedman and Schwartz $(1963,361)$ note. "We did not permit the inflow of gold to expand the U.S. money stock. We not only sterilized it, we went much further. Our money stock moved perversely, going down as the gold stock went up. .. . The result was that other countries not only had to bear the whole burden of adjustment but also were faced with continued additional disturbances in the same direction, to which they had to adjust." 
1920s and early 1930s. Johnson $(1997,147)$ contends that "while the United States did little to hinder the decline in world prices, especially after 1928, French policy can be charged with directly causing it." "That French gold policy aggravated the international monetary contraction from 1928 to 1932 is beyond dispute," Mouré $(2002,180)$ maintains. "The magnitude and timing of French gold absorption from mid-1928 to 1930 imposed a greater constraint on systemic monetary expansion than the gold accumulation in the United States during the same period." Even Milton Friedman later revised his view on the origins of the Great Depression and wrote that France also deserved some responsibility for its occurrence. ${ }^{5}$

Unfortunately, there is almost no quantitative evidence on the relative strength of deflationary forces emanating from the United States and France due to the withdrawal of gold from the rest of the world. Eichengreen (1990) finds that U.S. monetary gold stocks were three times and French gold stocks nearly five times that predicted based on estimated central-bank reserve demand from a cross section of countries. If the U.S. and French shares had been at their predicted levels, the gold reserves of other countries could have doubled and, "assuming that

${ }^{4}$ As Johnson notes, "Beginning in 1929, the price declines were triggered by the rapid concentration of gold in a small number of central banks, where it was partly or entirely sterilized (that is, the increase in reserves was not permitted correspondingly to increase the amount of currency or deposits). The Federal Reserve drew large amounts of gold from abroad starting in early 1929 and continuing through the summer of 1931, which contributed to the deflationary process; but this movement was exceeded by a larger amount flowing concurrently to the Bank of France. In addition, the gold inflow to France began earlier and persisted after the flow to the United States was reversed."

5 After re-reading the memoirs of the Emile Moreau, the governor of the Bank of France, Friedman (1991, xii-xiii) said that he "would have assessed responsibility for the international character of the Great Depression somewhat differently" than he did originally in his Monetary History with Anna Schwartz, namely by laying blame on France as well. Both the Federal Reserve and the Bank of France "were determined to prevent inflation and accordingly both sterilized the gold inflows, preventing them from providing the required increase in the quantity of money. . . . France's contribution to this process was, I now realize, much greater than we treated it as being in our [Monetary] History." 
central banks were concerned to retain some proportion between their reserves and domestic liabilities," Eichengreen concludes, "this redistribution of reserves would have provided considerable scope for an expansion of money supplies." Sumner (1991) uses a decomposition, rather than the estimated relationships and counterfactual analysis employed here, to find that central bank demand for monetary gold had a major impact of the world price level between 1926 and 1932. Although he does not focus on France in particular, his conclusions are consistent with this paper's findings and will be discussed below. Bernanke and Mihov (2000) also decompose national price movements due to changes in the money supply to components such as changes in the money multiplier, cover ratios, reserve to gold ratios, and the stock of gold. They conclude that the maldistribution of gold across countries and the sterilization of gold were broadly responsible for the early stages of the deflationary epoch, but they do not focus on the broader international consequences of France's policies.

This paper revisits the origins of the Great Depression to highlight the key role played by France. After examining France's monetary policy in the late 1920s, particularly its gold accumulation and sterilization policy, the paper estimates a simple model of the relationship between world prices and the world stock of monetary gold between 1875 and 1924. An out-ofsample forecast of the price level between 1925 and 1933 based on the actual changes in gold reserves suggests that, had the historical relationship between gold and prices continued, world prices would be expected to rise somewhat instead of declining 42 percent.

The paper then calculates how much gold would have been freed up if the United States and France had kept only enough to cover their actual liabilities at their 1928 cover ratios. By this measure, both countries held excess gold equivalent to 6 percent of the world gold stock in 1929 and 12 percent in 1930-32. While the United States and France contributed equally to the 
effective reduction in the world gold stock in 1929 and 1930, France was almost entirely responsible for the effective reduction in 1931 and 1932. The fact that the two countries kept such a large proportion of the world's gold stock inert and withdrawn from world circulation in 1929 and 1930 directly explains half of the massive worldwide deflation in 1930 and 1931 and is indirectly responsible for part of the remainder. Finally, an appendix surveys the views of a number of economists - Gustav Cassel, Allyn Young, and John Maynard Keynes - who anticipated many of these problems and warned of the dangers that would arise if central banks (France's in particular) began accumulating gold reserves without monetizing them.

These results support the view that France played a key role in bringing about the Great Depression. While France's role is sometimes acknowledged (usually briefly, if at all, however), economic historians have traditionally focused on the United States. Because of the country's smaller size, the impact of French policies is often believed to have been much smaller than the United States. ${ }^{6}$ Yet these findings suggest that the French role deserves much greater prominence than it has thus far received for having transmitted a tightening of monetary policy to other countries and thus beginning the worldwide deflationary spiral.

\section{The Controversy about France's Monetary Policy, 1928-1932}

Many of the international monetary difficulties of the late 1920 s can be traced to the decisions made to resume the gold standard in the mid-1920s after World War I. The Genoa conference of 1922 established guidelines (unenforceable ones, however) for the reconstructed gold standard. One concern at the time was that there would be insufficient new gold production to keep up with the growing demand for gold, and thereby result in deflation. Sweden's Gustav

${ }^{6}$ As Temin $(1989,22)$ writes: "American gold holdings were larger than those of the French, and the American influence on events was larger." 
Cassel was the leading economist who warned of an impending shortage of gold and the possibility of worldwide price deflation. Based on historical experience, he concluded that the world stock of monetary gold had to increase by about three percent a year to keep up with commercial activity and the growing demand for gold and thereby maintain the existing level of world prices. If the monetary gold stock grew more than 3 percent, world prices would increase; if the monetary gold stock grew less than 3 percent, world prices would fall. ${ }^{7}$

Cassel and others believed that world gold production was slowing and that this was a cause for concern because of the problems associated with deflation. He also thought that there would be higher demand for gold after the war because central banks had to support a larger base of liabilities due to the inflation that occurred during the war when the gold standard was suspended. The wartime inflation meant that nominal liabilities could not be covered by the existing monetary base of gold, so countries would either have to reset their exchange rate parities or accumulate more gold reserves. Fearful of the deflationary consequences of many central banks seeking to acquire more gold reserves at the same time, Cassel advocated a "goldexchange" standard in which foreign exchange holdings could also be used as central bank reserves to augment gold and thereby ensure stable prices. ${ }^{8}$

The Genoa conference endorsed the view that central banks should economize on the use of gold by using foreign exchange as part of their reserve base. Resolution No. 9 of the Conference recommended that central banks "centralise and coordinate the demand for gold, and so avoid those wide fluctuations in the purchasing power of gold which might otherwise result

${ }^{7}$ Because the nominal price of gold was fixed in terms of national currencies, an increase in the supply of gold would manifest itself not in a lower price of gold, but in a higher price of all other commodities. Similarly, an increase in the demand for gold would manifest itself in a lower price of all other commodities, not in a higher price of gold itself.

${ }^{8}$ Ralph Hawtrey, a leading monetary economist with the British Treasury who played a key role at the Genoa conference, shared many of these views. 
from the simultaneous and competitive efforts of a number of countries to secure metallic reserves." However, the Genoa resolutions were simply guidelines that could not be enforced. There was no agreement at all on the "rules" of gold standard game, particularly the idea that countries with increasing gold reserves should inflate their money supplies. In addition, many countries, France foremost among them, were skeptical of using foreign exchange reserves (such as British pounds) as part of its reserve base, fearing that such a policy would be inflationary.

The reconstructed gold standard started off on the wrong foot in 1925 when Britain rejoined it at an exchange rate that overvalued the pound (Moggridge 1969). This not only harmed the competitive position of export industries, but meant that the British balance of payments would remain in a fragile state until the country left gold in 1931. The balance of payments weakness required the Bank of England to maintain a tight monetary policy to sustain the pound at its high level, keeping interest rates high and thereby diminishing domestic investment. This kept economic growth in check and made it difficult for Britain to reduce its already high level of unemployment.

These problems were compounded in 1926 when France, after enduring a traumatic bout of inflation in 1924-26, stabilized the franc at an undervalued rate (Sicsic 1992). France also made two other key policy decisions: it rejected the British idea of a gold-exchange standard and chose to hold gold alone as part of its central bank reserves, and it decided to prevent any return of inflation by sterilizing gold inflows to prevent them from increasing domestic prices. ${ }^{9}$ France codified this set of policies with the Monetary Law of June 1928. This law officially restored

${ }^{9}$ As Mouré $(2002,188-89)$ notes: "The attitude of the Bank of France exemplified the asymmetry and the deflationary bias of the gold standard. The bank rejected the gold exchange standard as a dilution of the gold standard that promoted an over-expansion of credit ... The Bank of France set itself resolutely against measures to increase domestic monetary circulation and prices." 
convertibility of the franc in terms of gold at the undervalued rate, prevented the Bank from accumulating foreign exchange reserves, and required the Bank of France to maintain gold reserves equal to cover 35 percent of liabilities (notes in circulation and demand deposits). ${ }^{10}$

One of the main worries expressed by Cassel and acknowledged at the Genoa conference was that there would be a shortage of gold and deflation if new production of gold was insufficient to meet the growing demand for it. As it happened, the forecasts of declining gold production were off the mark. As Figure 1 shows, the supply of gold reserves continued to grow through the late 1920s and into the 1930s. In fact, world gold reserves increased 19 percent between 1928 and 1933 .

What changed, however, was the international distribution of those reserves. Partly as a result of the undervaluation of the franc, the Bank of France began accumulate gold reserves at a rapid rate. As Figure 2 shows, France's share of world gold reserves soared from 7 percent in 1926 to 27 percent in 1932. By 1932, France held nearly as much gold as the United States, though its economy was only about a fourth of the size of the United States. Together, the United States and France held more than sixty percent of the world's monetary gold stock in 1932.

The evolution of gold reserves in Figure 2 reveals much about the monetary policies in each country. The United States lost reserves (relative to other countries) between 1926 and 1928 due in part to large capital lending to Europe. After the Federal Reserve tightened policy in early 1928, foreign lending dried up and the U.S. share of reserves stabilized in 1929 and 1930.

${ }^{10}$ At the time, the gold cover ratio was 40 percent, or 63 percent with foreign exchange reserves (Mouré 1991, 47-48). It was understood that 40 percent was considered to be the minimum cover ratio so that the 35 percent would not be approached. 
The United States began losing reserves to other countries again in 1931 and 1932, after Britain left the gold standard in late 1931.

Figure 1: World Gold Reserves, 1925-1932

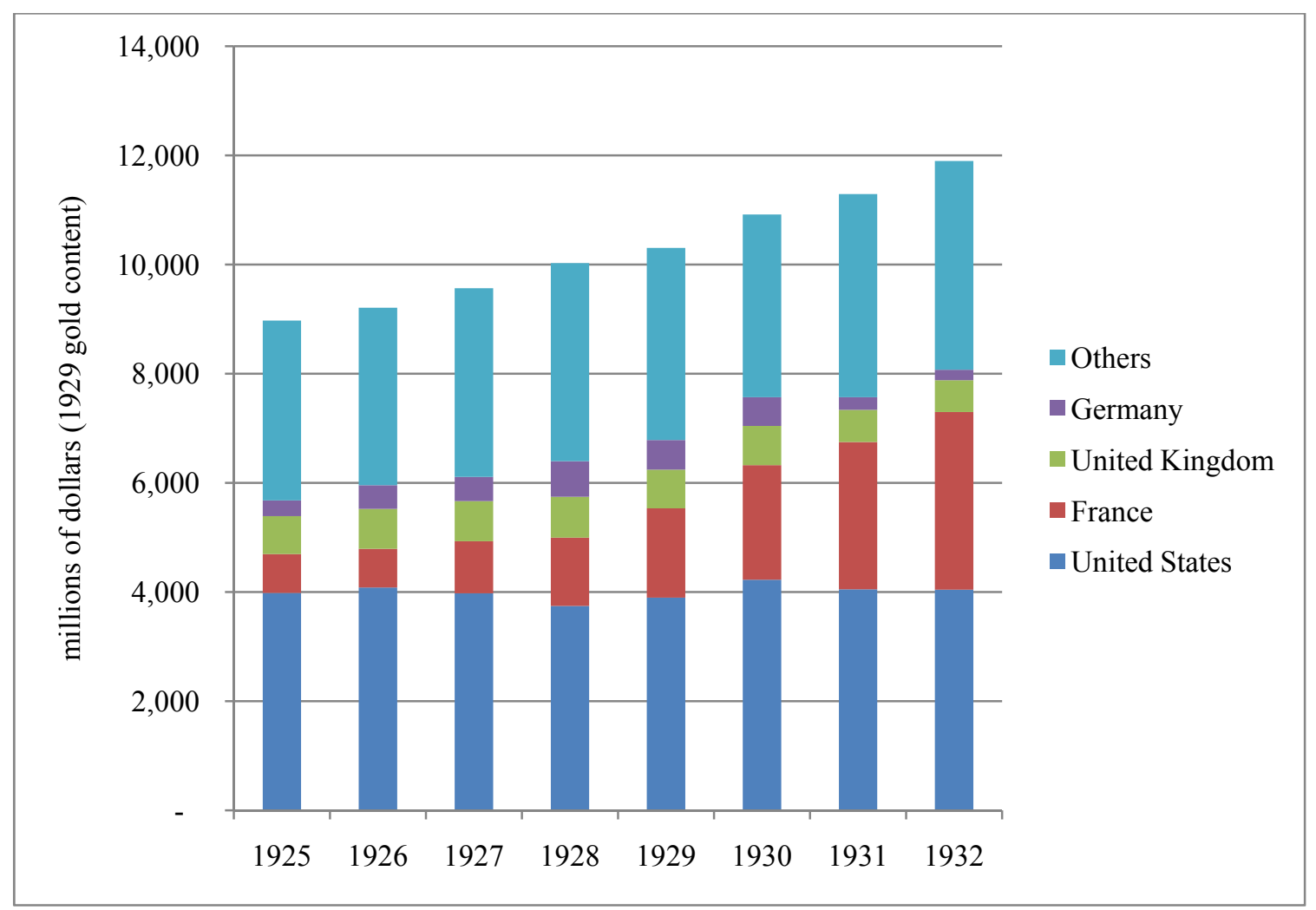

Source: Hardy $(1936,92)$. 
Between 1923 and 1926, France's share of gold reserves was stable, and about the same as Britain's. However, after the de facto stabilization of the franc occurred in 1926 (codified in 1928), France's share of world gold reserves took off. Its growth from 7 percent of world reserves in 1926 to 27 percent in 1932 is the astounding feature of this period. The Bank of France promoted this accumulation by selling off its foreign exchange reserves and purchasing gold. By liquidating its holdings of British pounds, France put pressure on the Bank of England's gold reserves and hence on British monetary policy. ${ }^{11}$

\section{Figure 2: Share of World Gold Reserves}

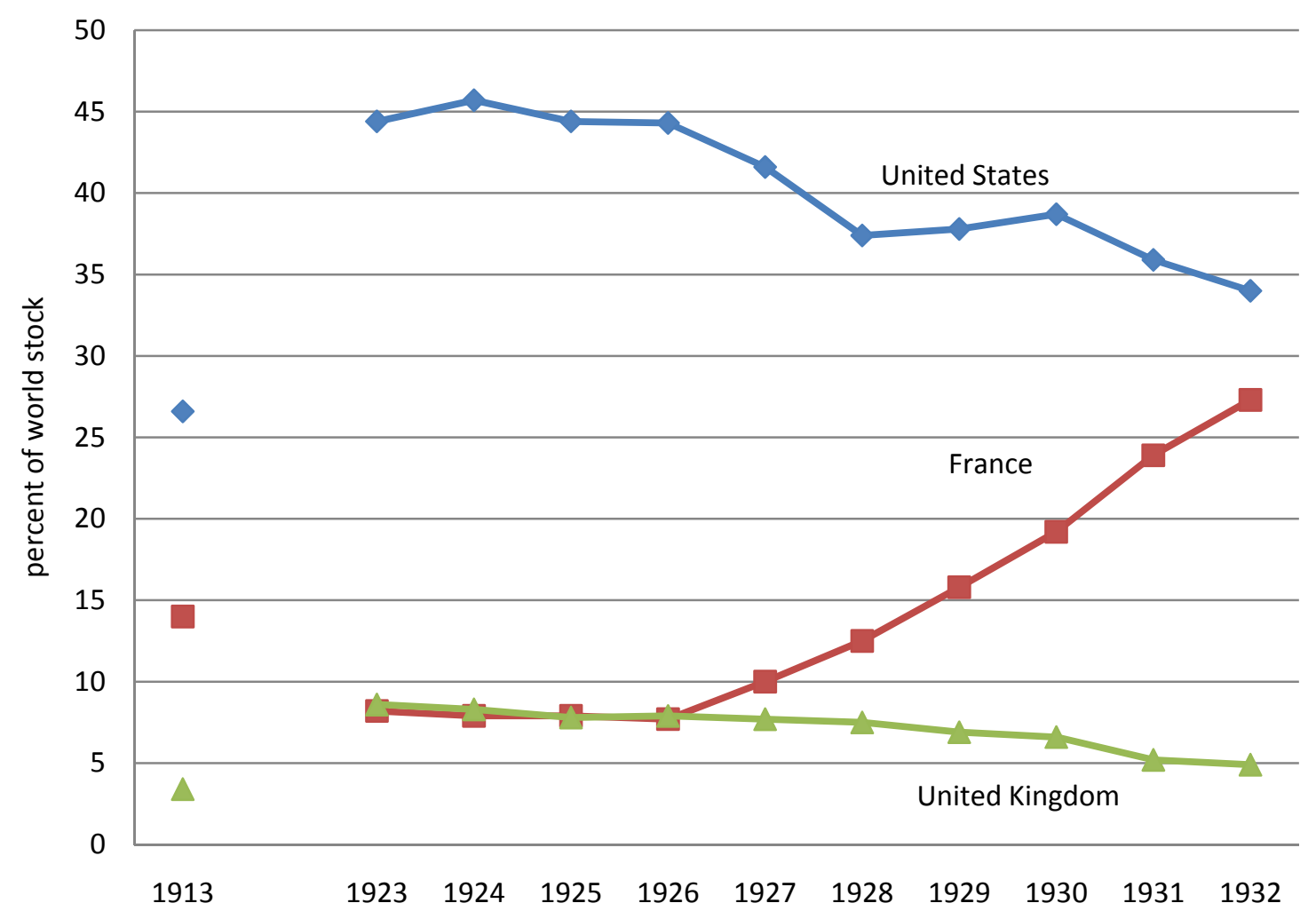

Source: Hardy $(1936,93)$

${ }^{11}$ See Accominotti (2009) for a recent discussion of the Bank of France's management of its foreign exchange portfolio. 
Meanwhile, the pressure on Britain due to the overvalued pound is also evident as its share of reserves gradually declined after 1925, and especially in 1931 when it faced large gold losses and was forced off the gold standard.

France's stabilization in 1926 and America's tightening of monetary policy in 1928 combined to attract gold to these two countries at the expense of the rest of the world. Table 1 provides another look at the change in gold reserves during this period. In December 1928, world gold reserves were 5 percent larger than they had been in December 1927; France accounted for 3 percent of the increase, the rest of the world 4 percent, while the United States lost 2 percent of the world stock. The situation changed in 1929 when the United States joined France in absorbing most of the growth in gold reserves and then some, taking 3 percent of the world stock away from the rest of the world. The same thing happened in 1930 as well. In 1931, the world gold stock rose 3 percent, but France accumulated 8 percent, taking 2 percent of the world gold stock away from the United States and 3 percent away from the rest of the world.

The deflationary pressure that this redistribution of gold put on other countries is remarkable. In 1929, 1930, and 1931, the rest of the world lost the equivalent of about 8 percent of the world's gold stock, an enormous proportion - 15 percent - of the rest of the world's December 1928 reserve holdings.

The cumulative effect is astounding. In December 1932, world gold reserves were 24 percent larger than they had been in December 1927. However, France absorbed almost every ounce of the additional gold, leaving the rest of the world with no net increase. ${ }^{12}$ The United

${ }^{12}$ John Maynard Keynes $(1932,83)$ could not resist this biting remark: "And, when the last gold bar in the world has been safely lodged in the Bank of France, that will be the appropriate moment for the German Government to announce that one of their chemists has just perfected the technique for making the stuff at $6 \mathrm{~d}$. an ounce." 
States seems to have been less of a problem because it was not systematically accumulating gold throughout the period.

Table 1: Gold Reserves: Percentage Change from Previous year

\begin{tabular}{|l|c|c|c|c|}
\hline & $\begin{array}{c}\text { Total World Gold } \\
\text { Reserves }\end{array}$ & \multicolumn{3}{|c|}{$\begin{array}{c}\text { Absorption by } \\
\text { (percent of total world reserves) }\end{array}$} \\
\hline & & United States & France & Rest of World \\
\hline December 1928 & +5 & -2 & +3 & +4 \\
\hline December 1929 & +3 & +2 & +4 & -3 \\
\hline December 1930 & +6 & +3 & +5 & -2 \\
\hline December 1931 & +3 & -2 & +8 & -3 \\
\hline December 1932 & +5 & +0 & +3 & +3 \\
\hline Cumulative percentage change from December 1927 & +1 & +21 & -4 \\
\hline December 1931 & +18 & +1 & +24 & -0 \\
\hline December 1932 & +24 & & & \\
\hline
\end{tabular}

Note: final three columns may not sum to first column due to rounding.

Source: Board of Governors of the Federal Reserve System (1943), pp. 544-545.

This massive redistribution of gold would not have been a problem for the world economy if the United States and France had been monetizing the gold inflows. Then the gold inflows would have led to a monetary expansion in those countries, just as the gold outflows from other countries led to a monetary contraction elsewhere. That would have been playing by 
the "rules of the game" of the classical gold standard. However, there were no agreed-upon rules of the game in the interwar gold standard. And both France and the United States were effectively sterilizing the inflows to ensure that they did not have an expansionary effect. ${ }^{13}$

The sterilization is implicit in the cover ratios presented in Figure 3. The cover ratio is the ratio of central bank gold reserves to its domestic liabilities (notes in circulation and demand deposits). Once again, the change in France is astonishing in comparison to the other countries. As noted earlier, the Monetary Law of 1928 mandated the cover ratio of the Bank of France to be a minimum of 35 percent, although the Bank wanted a minimum of 40 percent in practice. This is about where the cover ratio was in December 1928. Of course, this was a lower bound and there was no maximum cover ratio beyond which the Bank was forbidden to go. By 1930, the Bank of France cover ratio rose to over 50 percent. In January 1931 it reached 55 percent; at this point the Bank of France considered but rejected a proposal to suspend its gold purchases (Mouré 2002, 188). By 1932, the cover ratio had risen to the astounding level of nearly 80 percent! France was well on its way to having 100 percent money, in which all of the central bank liabilities would be backed one-for-one with gold in its vault.

The path of the U.S. cover ratio is also consistent with the previous discussion. The cover rose in 1929 and 1930 as a result of the Federal Reserve's tightening in 1928. In those years the United States was accumulating gold and its cover ratio was increasing. However, when the United States began to lose gold in 1931 and 1932, the cover ratio also fell. Thus, the Federal Reserve's policy was symmetric: it did not inflate when gold was coming in and it did not deflate when it lost gold reserves. Once again, by this measure, U.S. policy is somewhat

${ }^{13}$ Eichengreen (1986) examines France's sterilization policy in detail. 
tighter in 1929 and 1930, but somewhat looser in 1931 and 1932, whereas France is consistently tight - and seemingly to a greater degree than the United States - throughout this period.

Meanwhile, Britain's cover ratio was the lowest of the three and declined slightly as the Bank of England struggled to keep a hold of its existing gold reserves.

Figure 3: Cover Ratios of Major Central Banks, 1928-1932

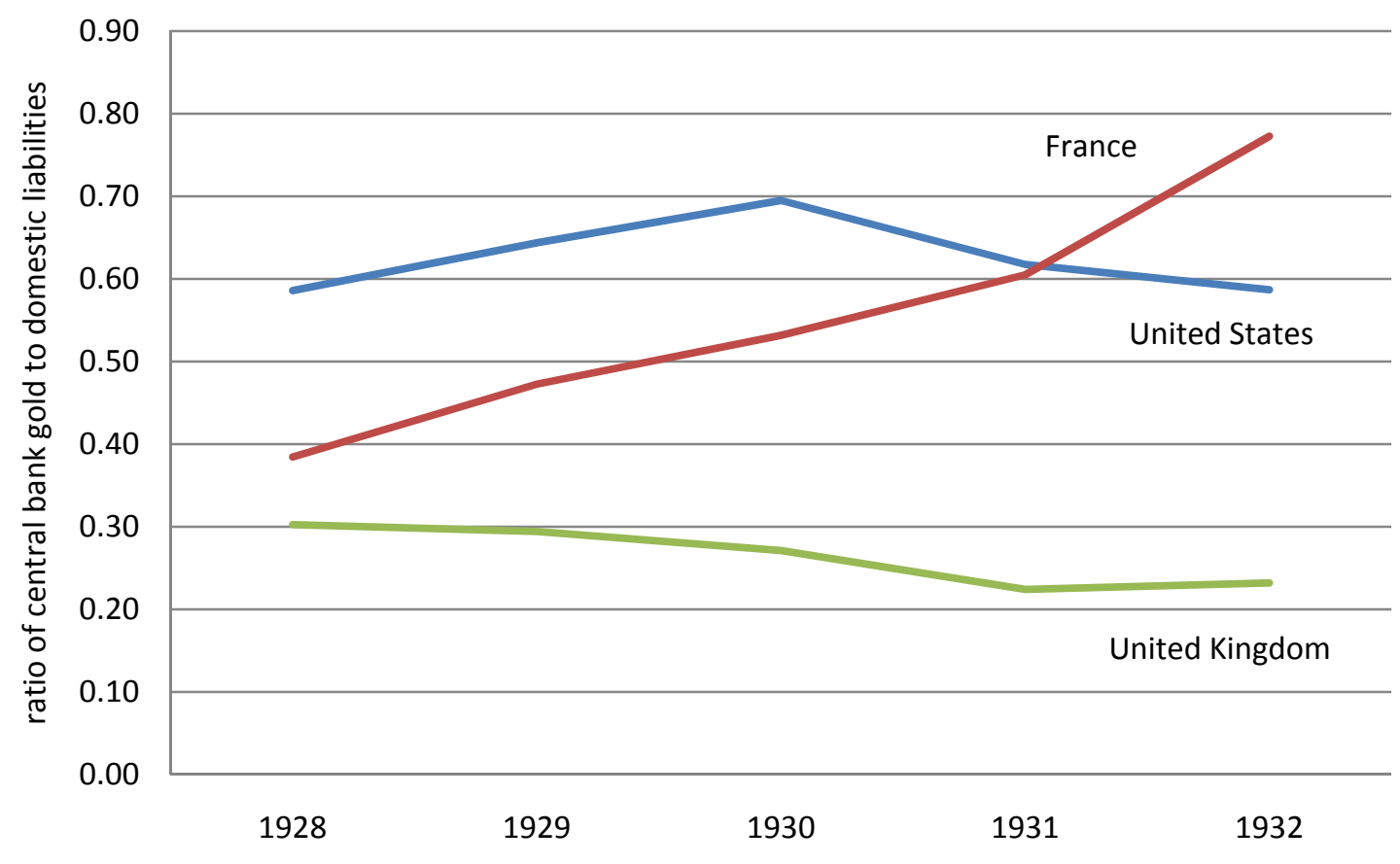

Note: Data are for December of each year.

Source: Calculated from the Board of Governors of the Federal Reserve System (1943).

While French policy was largely passive with respect to the gold inflows, the undervaluation of the franc in 1928 played a major role in generating the balance of payments surpluses that were driven by gold inflows. French officials such as Rist (1931) argued that the inflows represented confidence in their economic policies and that they were doing nothing to 
encourage the gold movement. Sicsic (1993) notes that the capital inflows arose from the repatriation of capital by French residents after the stabilization became credible. Yet as Mouré $(2002,187)$ points out, this still created problems for the international financial system because even if all the gold coming back was repatriated capital, it had left the country without producing any decline in French gold reserves while it returned to France by delivering gold from the rest of the world.

French officials not only disclaimed responsibility for the gold inflows, they denied sterilizing gold. Finance Minister Paul Reynaud $(1933,258)$ pointed out that new francs had been issued in almost equal value to the amount of gold accumulated between 1928 and 1932 "as is required by the gold standard system." (Reynaud failed to note that a decline in commercial banks deposits had largely offset the increase in note issue.) In fact, a closer look at the balance sheet of the Bank of France indicates that it was not sterilizing in the classic sense of reducing domestic assets to offset an increase in foreign assets. As Table 2 indicates, the Bank continued to accumulate domestic assets even as its foreign asset holdings grew. The Bank's total assets grew 29 percent between 1928 and 1932, although this understates the growth because the Bank did not treat foreign exchange as part of its monetary base; total assets of gold and domestic assets grew 102 percent.

And yet, despite this growth in the monetary base, the money supply was essentially unchanged over this period. The implicit money multiplier dropped and offset the increase in high powered money. Figure 4 presents another depiction of France's reserves of gold, gold and foreign exchange, and money supply (M2). Simply put, the growth in the Bank's total assets was not getting translated into the nation's money and credit. 
Table 2: Bank of France's Balance Sheet, 1928-32

Millions of francs, end of December of each year

\begin{tabular}{|c|c|c|c|c|c|c|c|}
\hline \multirow[t]{2}{*}{ Year } & \multicolumn{3}{|c|}{ Foreign Assets } & \multirow{2}{*}{$\begin{array}{c}\text { Domestic } \\
\text { Assets }\end{array}$} & \multirow{2}{*}{$\begin{array}{c}\text { Total Assets } \\
\text { (monetary base) }\end{array}$} & \multirow{2}{*}{$\begin{array}{c}\text { Money } \\
\text { Supply (M2) }\end{array}$} & \multirow{2}{*}{$\begin{array}{l}\text { Money } \\
\text { multiplier }\end{array}$} \\
\hline & Gold & $\begin{array}{l}\text { Foreign } \\
\text { Exchange }\end{array}$ & Total & & & & \\
\hline 1928 & 32.0 & 32.7 & 64.7 & 19.9 & 84.6 & 161.7 & 1.91 \\
\hline 1929 & 41.7 & 25.9 & 67.6 & 22.4 & 90.0 & 161.5 & 1.80 \\
\hline 1930 & 53.6 & 26.2 & 79.8 & 23.2 & 103.0 & 170.2 & 1.65 \\
\hline 1931 & 68.8 & 21.1 & 89.9 & 25.8 & 115.8 & 164.7 & 1.42 \\
\hline 1932 & 83.0 & 4.5 & 87.5 & 21.9 & 109.5 & 163.7 & 1.50 \\
\hline $\begin{array}{l}\text { Percentage } \\
\text { Change } \\
(1928-32)\end{array}$ & +159 & -86 & +35 & +10 & +29 & +1 & -- \\
\hline
\end{tabular}

Source: Assets from Board of Governors of the Federal Reserve System (1943), pp. 641-642. M2 from Patat and Lutfalla (1990), Table A2. 
Figure 4: France's Monetary Indicators, 1926-1932

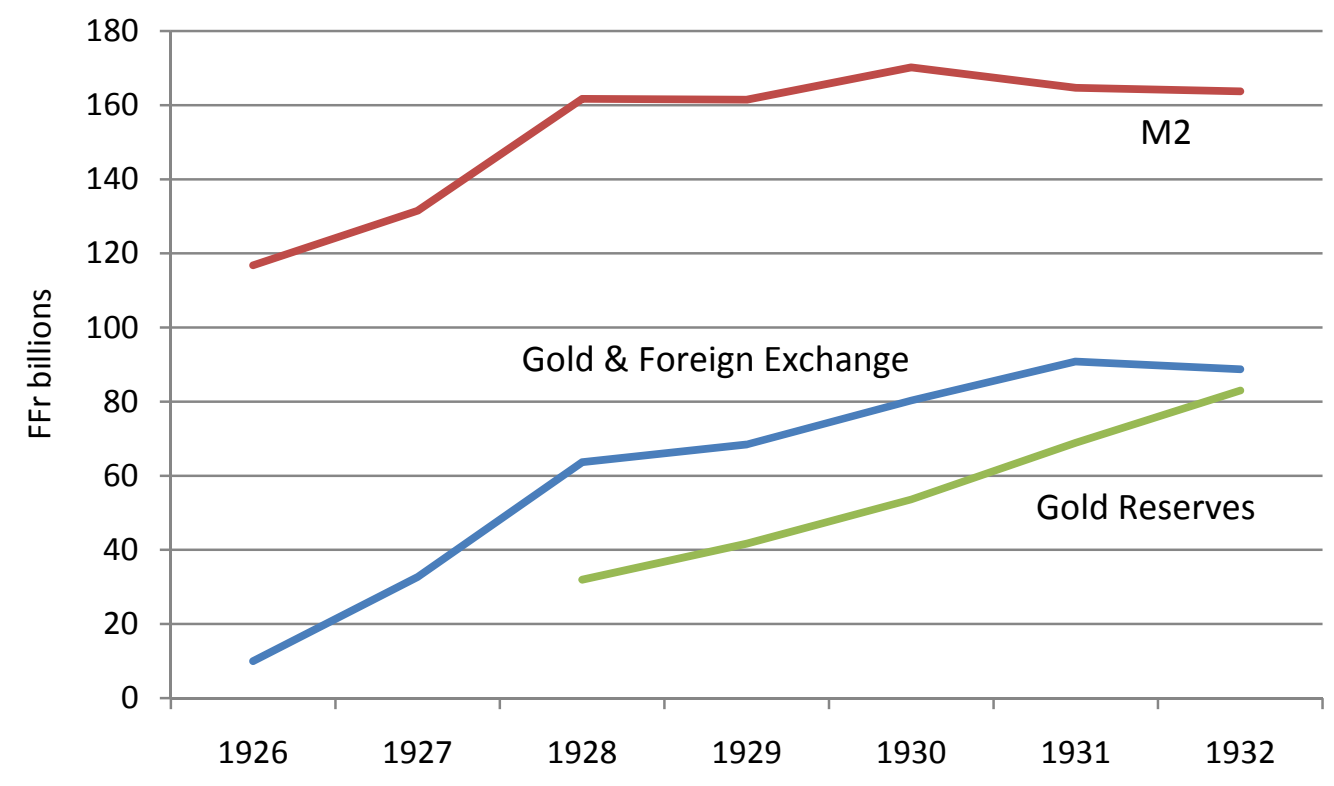

Source: Patat and Lutfalla (1990, Table A2) and Mouré (1991, 55-56).

To some extent, the falling money multiplier was beyond the direct control of the Bank of France. ${ }^{14}$ As Eichengreen (1986) emphasizes, there were a variety of institutional and legal

${ }^{14}$ Bernanke and Mihov (2000, 139-40, 148-150) note that "the falling money multiplier combined with the Bank of France's movement from foreign exchange reserves to gold accounts for essentially the entire nullification of the effect of the gold inflows on the domestic money supply. . . given the French commitment to the gold standard,, and to exclusive reliance on gold reserves, the actions of the Bank of France are difficult to fault . . . [they] conducted policy almost entirely according to the 'rules of the game' because of the stability of the monetary base to international reserve ratio. ... This is not to claim that French monetary policies were not bad, even disastrous, for the world as a whole: in particular, the large gold inflows induced by the conversion of foreign exchange and the switch by French citizens from deposits to currency put major pressure on other gold standard countries to tighten their monetary policies. However, the damage done by French policies lay to a much greater degree in the government's choice of monetary regime - its commitment to the gold standard, with minimal use of foreign exchange 
reasons for the inability of France to translate its expanding gold reserves into the monetary supply. Under the Monetary Law of 1928, the Bank of France was restricted in its ability to undertake open market operations to ease the monetary situation and slow the gold inflows. Government fiscal surpluses were deposited at the Bank of France and built up as idle balances because of the fear of monetization and inflation, as occurred before the 1926 stabilization. The French banking system was also notoriously inefficient at transforming reserves into francs. Given the legal restrictions on the Bank of France and institutional environment, Eichengreen (1986) concludes that there were few policies (except open market operations, had that been available) that could have stopped the French gold accumulation. ${ }^{15}$

Yet, even if it could have done more, French policymakers were not inclined to do anything much differently. French officials were satisfied with the situation and did not see why any changes should be made. Although the Bank of France only considered gold as part of its reserve base, its defenders pointed out that the composition of its reserves had simply shifted from foreign exchange to gold, so its total asset position had not grown as much as commonly thought. Yet even including foreign exchange holdings, the Bank of France's cover ratio grew sharply during this period.

In fact, France wanted to maintain a high cover ratio. Despite the expanding reserve base, the Bank of France did not want to undertake any "inflationary" monetary policy and so it took measures to limit the impact of gold on monetary circulation. "It would have been

reserves - than in the Bank of France's implementation of that regime."

${ }^{15}$ Eichengreen (1986) argues that "France's painful experience with inflation in the early 1920s was directly responsible for the adoption of the stringent regulations which prevented the central bank from intervening to prevent the accumulation of gold." He suggests that "viewing French attitudes in their historical context sheds more light on the actions of policymakers than do allegations of obstinacy or of failure to understand the workings of the international monetary system." 
extremely imprudent of the Bank to put all its gold to work, even had that been possible," Reynaud (1933, 258-60) argued. "The Bank of France has the duty to be forearmed against the possibility of a sudden withdrawal of foreign funds. . . . It is the duty of the Bank of France to guard against this danger by maintaining, not a sterile gold reserve, but a margin of available credit, so that it may intervene at an opportune moment and so far as possible modify the effect produced by the withdrawal of foreign capital."16

Figures 2, 3, and 4 illustrate why France was viewed as a "gold sink" by contemporary observers. As one might expect, French policy led it into conflict with British officials, who were well aware that France's policy was making its own adjustment difficult in view of the overvalued pound. In January-February 1931, British officials consulted with their French counterparts to see if they could be moved from their monetary stance. French officials insisted that the gold inflow demonstrated market confidence in its good policies, that they had done nothing deliberate to increase the gold inflow, and that there was nothing that they could do to stop it (Mouré 2002, 183-86, Boyce 1987, 296-99). They put the burden on Britain to raise interest rates further if they wished to attract gold. The French explanation failed to satisfy British officials. As Ralph Hawtrey put it: "We complain of the drain of gold because it tends to cause a monetary contraction here and in the rest of the world, and Monsieur Escallier's reply is that we can prevent the drain of gold if we choose to effect a monetary contraction!" (Mouré $1991,63)$.

16 Reynaud $(1933,260)$ also tried to cast French policy in a favorable light in comparison to the Federal Reserve: "Unlike the United States, the Bank of France has never tried to neutralize the influx of gold into France. It felt that such a policy, by maintaining artificial credit conditions, would actually have stimulated the import of gold and aggravated the monetary difficulties of other countries." 
France's refusal to make any concessions infuriated many in Britain. Financial journalist Paul Einzig (1931, vii) vehemently denounced French policy, arguing that it is "the French goldhoarding policy which brought about the slump in commodity prices, which in turn was the main cause of the economic depression; that it is the unwillingness of France to cooperate with other nations which has aggravated the depression into a violent crisis; and that her unwillingness to co-operate is still the principal obstacle to an economic recovery." Einzig contended that the gold reserves gave France political power that it could exploit; indeed, French officials made threats at various points to sell some of its foreign exchange holdings of certain countries to induce them to agree to French foreign policy objectives, although there is less evidence that such threats were used. ${ }^{17}$

To conclude, there is a plausible case that French monetary policy was more problematic for the world than American monetary policy from 1928 to 1932. Empirical evidence is needed to see if that is true.

\section{Gold and Prices, Reserves and Cover Ratios: A Counterfactual Assessment}

Any assessment of the worldwide deflationary impact of U.S. and French monetary policies in the late 1920s requires a simple empirical framework for relating world prices to the underlying stock of monetary gold. Cassel (1928), Kitchen (1930), and Warren and Pearson (1933, 80-81) all discussed how world commodity prices were influenced by changes in the world gold stock. All emphasized the same result: that monetary stock of gold would have to increase about 3 percent per year to maintain stable world prices; if the monetary stock rose at a

${ }^{17}$ Mouré $(2002,191)$ finds that "Bank of France records reveal no direct political motives at work; such motives seemed obvious, however, to critics seeking to explain the gold flow to France in 1930, and would be evident in central bank efforts to deal with the financial crises of 1931." 
slower rate, prices would fall; if the stock rose at a more rapid rate, prices would rise. They showed this empirical regularity with an abundance of charts and tables (no regression analysis, of course) that depicted the world gold stock and a measure of world commodity prices dating back to the 1840 s. The most frequently used measure of world prices was the Sauerbeck-Statist index, a longest available series of world commodity prices that dated back well into the early nineteenth century.

In fact, consistent with the contentions of these early analysts, a simple empirical model performs reasonably well in explaining prices. Let $\mathrm{P}$ be the level of wholesale prices (as measured by the Sauerbeck-Statist index) and G be the world's stock of monetary gold. Because changes in the stock of gold would affect prices with a lag, consider the following specification:

$$
\Delta \log \mathrm{P}_{\mathrm{t}}=\alpha+\beta \Delta \log G_{t-1}+u_{t}
$$

The constant term can be interpreted as the change in the price level if there was no growth in the supply of gold. We would expect the estimate of alpha to be about -0.03 , if Cassel and others were correct. The coefficient $\beta$ gives us the elasticity of the gold stock with respect to commodity prices. Because the coefficient is akin to the money multiplier, we would expect our estimate of beta to be greater than one but less than three. The estimate is related to the reciprocal of the world cover ratio; if the world cover ratio is 0.4 , on average, then the goldmoney-price multiplier would be about 2.5 .

This specification is completely supply-side driven and ignores the fact that a lower price level (i.e., a higher relative price of gold) should lead to an increase in production of gold. However, gold production is relatively inelastic in the short-run, particularly with respect to short-term, year-to-year price fluctuations. ${ }^{18}$ Yet even over the longer run, Rockoff (1984) finds

\footnotetext{
${ }^{18}$ As Sumner $(1991,383)$ notes: "changes in the supply of monetary gold could only
} 
that changes in gold supply prior to 1913 were largely determined by factors other than the price of gold.

Another issue is the length of lags to be considered. Gold would not expected to have an immediate impact on prices, but the lag between its appearing in a central bank's reserves and its being monetized to affect prices could be long and variable. Cassel and others thought up to three to five years before changes in gold would pass through to prices. In fact, in considering various specifications, the contemporaneous impact of gold is often insignificant or of the wrong sign, and additional lags beyond the second are insignificant. The coefficient on the first lag is comparable to the sum of the coefficients in a distributed lag specification. For simplicity, we will focus on the simple one-lag specification.

Table 3 reports the results from estimating this equation with the world monetary gold stock and wholesale price index data presented in League of Nations (1930, 82-84). ${ }^{19}$ Column 1 reports the estimates using annual data from 1840 to 1914 and finds that the constant term $\alpha$ is estimated to be -0.04 and $\beta$ is estimated to be 1.16 . However, the coefficient on gold is likely to be biased because silver was also used as a monetary standard for much of the early part of this period. Column 2 focuses on the period of the classical gold standard from 1875 to 1914 . The constant term is -0.04 and is statistically significant. This finding supports Cassel's contention that the demand for gold was growing at about three percent annually and therefore world gold supplies would need to expand at least that much to maintain prices. The coefficient on the lagged change in the monetary gold stock is 1.5 and is statistically significant at the five percent level. The coefficient indicates that a 10 percent increase in gold would translate into a 15

slightly reduce the impact of changes in gold-reserve ratios on the price level, at least in the short- to medium-term."

${ }^{19}$ The Sauerbeck-Statist index after 1929 comes from Mitchell (1988). 
percent increase in wholesale prices in the subsequent year. Column 3 estimates the same equation with dummy variables for each decade and finds a somewhat larger coefficient on gold.

Did the same relationship between gold and prices hold in the 1920s? The gold standard was suspended during World War I and thereafter, so prices and gold became delinked. Prices rose sharply during the war, and fell precipitously in 1921. Column 4 shows the results from estimating the same equation for the period 1875 to 1924, but with dummy variables for World War I (1915-17), the postwar price decline (1921), and the early postwar period (1922-24). The coefficient on gold is slightly lower, at 1.38 . Column 5 repeats the regression but includes decade dummy variables, and the coefficient on gold is about 1.5. If one extends the sample past 1924, however, the coefficient on gold drops precipitously. This reflects that fact that the changes in world gold reserves were no longer getting translated into world prices. This reflects the start of the malfunctioning of the interwar gold standard. 
Table 3: Estimates of Price-Gold Relationship

\begin{tabular}{|c|c|c|c|c|c|}
\hline & 1 & 2 & 4 & 4 & 5 \\
\hline Sample Period & $1840-1914$ & $1875-1914$ & $\begin{array}{c}1875- \\
1914\end{array}$ & $1875-1924$ & $1875-1924$ \\
\hline$\alpha$ & $\begin{array}{l}-0.04^{*} \\
(0.02)\end{array}$ & $\begin{array}{l}-0.04 \\
(0.01)\end{array}$ & $\begin{array}{l}-0.05 \\
(0.01)\end{array}$ & $\begin{array}{l}-0.04^{*} \\
(0.01)\end{array}$ & $\begin{array}{l}-0.01 \\
(0.01)\end{array}$ \\
\hline$\beta$ & $\begin{array}{l}1.16^{*} \\
(0.35)\end{array}$ & $\begin{array}{l}1.50 * \\
(0.48)\end{array}$ & $\begin{array}{c}1.89 * \\
(0.90)\end{array}$ & $\begin{array}{l}1.38 * \\
(0.46)\end{array}$ & $\begin{array}{l}1.51 * \\
(0.69)\end{array}$ \\
\hline $\begin{array}{l}\text { World War I } \\
(1915-1917)\end{array}$ & -- & -- & -- & $\begin{array}{l}0.21 * \\
(0.01)\end{array}$ & $\begin{array}{l}0.19 * \\
(0.01)\end{array}$ \\
\hline $\begin{array}{l}\text { Post-War } \\
\text { Adjustment } \\
(1921)\end{array}$ & -- & -- & -- & $\begin{array}{l}-0.42 * \\
(0.01)\end{array}$ & $\begin{array}{l}-0.45^{*} \\
(0.01)\end{array}$ \\
\hline $\begin{array}{l}\text { Post-War } \\
\text { Period } \\
(1922-1924)\end{array}$ & -- & -- & -- & $\begin{array}{c}0.01 \\
(0.01)\end{array}$ & $\begin{array}{l}-0.01 \\
(0.02)\end{array}$ \\
\hline $\begin{array}{l}\text { Decade } \\
\text { Dummy } \\
\text { Variables }\end{array}$ & No & No & Yes & No & Yes \\
\hline $\mathrm{N}$ & 73 & 40 & 40 & 50 & 50 \\
\hline $\mathrm{R}^{2}$ & 0.16 & 0.17 & 0.23 & 0.82 & 0.84 \\
\hline
\end{tabular}

Note: HAC standard errors in parenthesis; * indicates statistical significance at the 5 percent level. 
The close historical relationship between the change in world gold reserves and the change in world prices in the subsequent year provides a basis for forecasting the path of prices in the late 1920s and early 1930s based on the actual change in the world's monetary gold stock. The monetary gold stock grew 18 percent between 1928 and 1933, a compound annual rate of 3.4 percent. Despite the concerns about an insufficient supply of gold, there was no apparent shortage of monetary gold during this period. As a result, world prices would have been forecasted to rise about 15 percent over this five year period. Instead, world prices fell 42 percent between 1928 and 1932.

Figure 5 shows actual world prices from 1875 to 1933, predicted world prices from 1875 to 1924 (from equation 5 in Table 2), and the out-of-sample forecast of prices from 1925 to 1933. This illustrates the powerful deflationary shock that hit during this period. It is very difficult to see how a price decline of this magnitude could have been anticipated based on the growing supply of gold during this period. ${ }^{20}$ For some reason, the world's monetary gold stock was not being translated into world prices. The likely reason for this was the increased demand for gold by France and the sterilization of gold by France and the United States.

${ }^{20}$ See Hamilton (1992) and Evans and Wachtel (1993) for evidence that the deflation was not anticipated. 
Figure 5: Actual and Predicted Wholesale Prices, 1840-1928

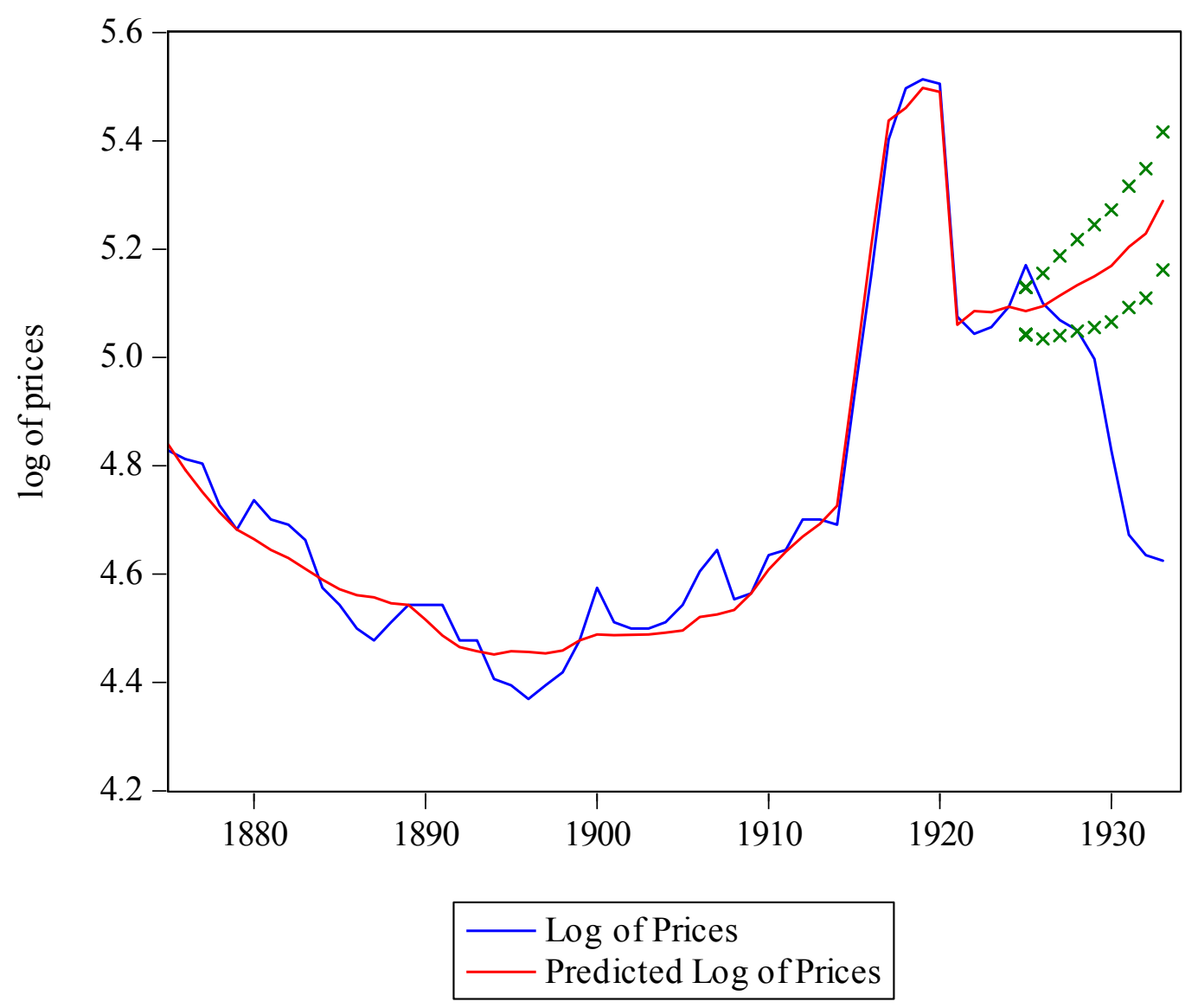

Note: plus and minus two standard errors included with the forecast price level 
The precise timing of the deflationary price shock is closely related to the changes in French and American monetary policies. In most countries, wholesale prices were stable in the mid-1920s. The world economy was doing reasonably well and, while there were the usual difficulties with reparations and the like, there was no obvious indication that the world could not muddle through -- until a powerful deflationary shock struck countries simultaneously in mid1929, as Figure 6 shows. This suggests that something must have occurred in 1928 to bring about the changes in prices in 1929. What happened in 1928 is the tightening of Federal Reserve policy coincided with the growing strength and importance of the French gold sink. France's policy had been a net drain on world gold reserves as early as 1926, but its effect had been offset by U.S. gold exports between 1926 and 1928, as noted earlier and pointed out by Sumner (1991).

Figure 6: Wholesale Prices, 1926-1932

Source: League of Nations, Statistical Yearbook of the League of Nations 1931/32.

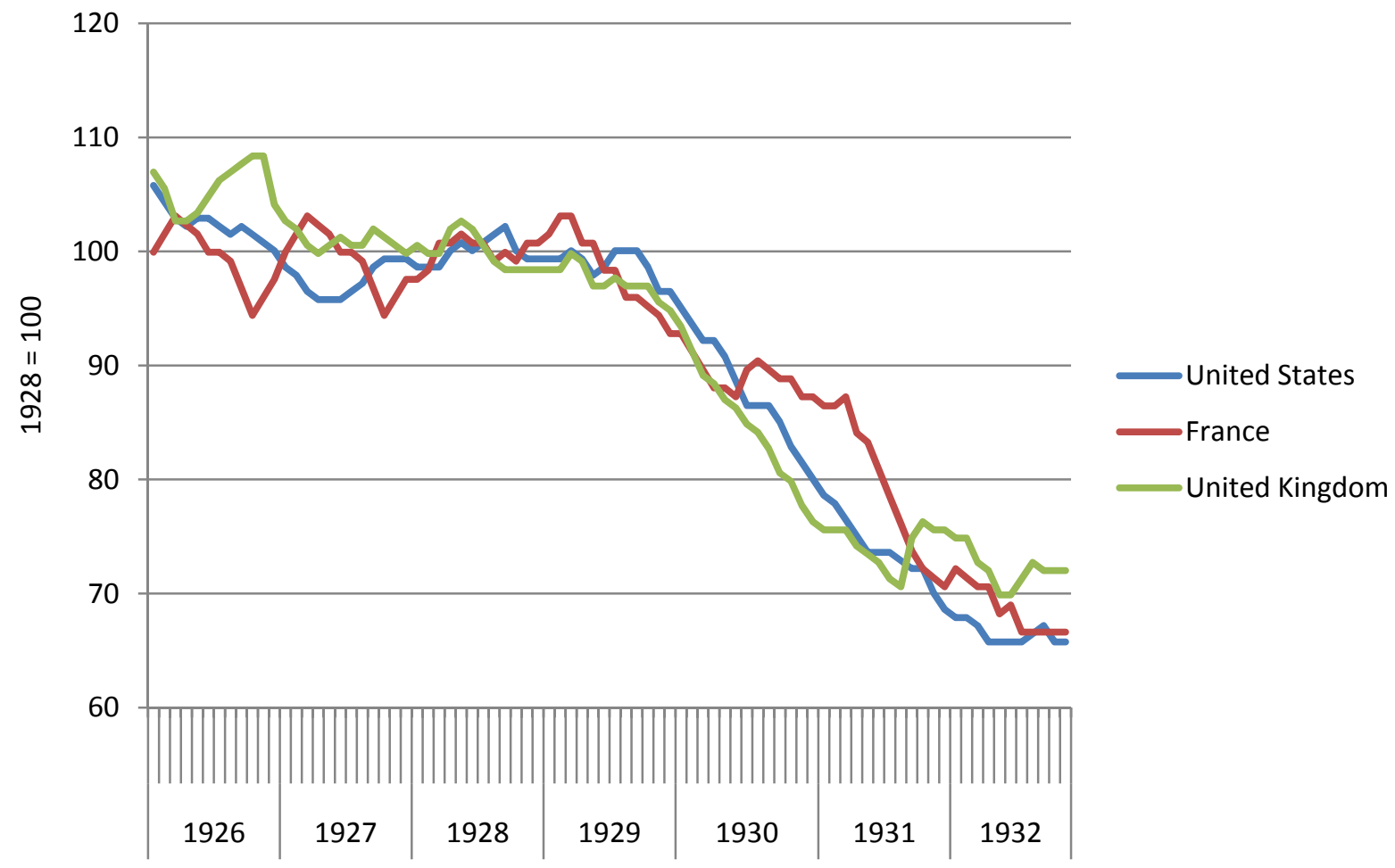


The identification of monetary changes in 1928 as leading to price changes in 1929 is consistent with Gustav Cassel's contemporary analysis of the situation. Cassel was a member of a League of Nations delegation charged with studying the gold situation. ${ }^{21}$ The report attributed the problems of 1929-32 to "maladjustments" and "disruptions" in the world economy as a result of World War I. Cassel rejected this view and refused to sign the final report when it was issued in 1932. In his dissenting note, Cassel argued that this vague formulation avoided any recognition that specific policy changes in France and the United States might have been responsible for the troubles. Cassel (1932a, 74) stated that

"the way in which the Gold Delegation presents the causes of the breakdown of the gold standard seems to me entirely unacceptable. What we have to explain is essentially a monetary phenomenon, and the explanation must therefore essentially be of a monetary character. An enumeration of a series of economic disturbances and maladjustments which existed before 1929 is no explanation of the breakdown of the gold standard. In fact, in spite of existing economic difficulties, the world enjoyed up to 1929 remarkable progress. What has to be cleared up is why the progress was suddenly interrupted." In other words, the question was why a deflationary shock suddenly appeared in mid1929 and why it hit so powerfully - and unrelentingly - over the next three years. What happened, in Cassel's view, was simply an increase in the monetary demand for gold from the United States and France that produced a "rise in the value of gold [i.e., reduction in world prices] of unparalleled violence."

${ }^{21}$ For political reasons, the report had to tip-toe around France's policies (less so for the United States, which was not a member of the League and hence could not use pressure to vet the report). See Clavin and Wessels (2004). 
"The consequence was such a drain on the gold reserves of other countries as to cause the breakdown of the international gold-standard system. The sudden increase in the value of gold meant a corresponding fall in the general level of commodity prices, the effect of which was a general distrust and unwillingness to invest savings in production and a widespread incapacity of debtors - private and public - to meet their obligations, causing a further destruction of confidence."

The impact of the French and American monetary policies starting in 1928 can be assessed by calculating how much gold was sitting "inactive" in the vaults of the Federal Reserve and the Bank of France. Then the effect of this sterilized gold on world prices can be traced back using the regression coefficients presented in Table 3. Given that the world economy seemed to be doing reasonably well in 1928, the year in which the Federal Reserve began to tighten monetary policy and the Bank of France officially began operating under the new Monetary Law, that year will be taken as a benchmark. ${ }^{22}$

The key assumption will be that the two countries fix their cover ratio - the ratio of gold reserves to domestic liabilities (notes in circulation and demand deposits) - at their 1928 levels in subsequent years. Letting $\mathrm{G}$ stand for the gold reserves and $\mathrm{L}$ for domestic liabilities, the reserve ratio " $r$ " for the 1928 benchmark can be calculated as $r_{28}=G_{28} / L_{28}$, as depicted in Figure 3. The amount of excess gold held in 1929 can be calculated as $G_{29}-r_{28} \cdot L_{29}$, where $r_{28} \cdot L_{29}$ is the amount of gold required in 1929 to maintain the same 1928 cover ratio for the actual amount of outstanding liabilities in 1929. This can be calculated for subsequent years in the same way.

Figure 7 presents the results graphically and reports the excess gold as a share of the world's gold stock. In 1929, the United States and France had "excess" and sterilized reserves

${ }^{22}$ In addition, the balance sheet of the Bank of France is wholly different prior to the Monetary Law, making it difficult to use 1927 as a benchmark year. 
equivalent about 6 percent of the world's gold stock, each accounting for about 3 percent. This means that about 6 percent of the world's gold stock was effectively withdrawn from world circulation and de-monetized. That gold became "inactivated" in 1929 in the sense that it was held above what would have been required to maintain the 1928 cover ratio, given the actual outstanding liabilities in 1929. Although France's gold reserves grew much faster than the United States in 1929, at 30 percent versus 4 percent, the U.S. gold stock was much greater. Because the increase in the cover ratio was similar across the two countries, the absolute amount of the excess gold reserves was nearly identical.

In 1930, when the United States and France held about 60 percent of the world's gold stock, they were sitting on (non-monetizing) about 11 percent of the world's gold stock compared to 1928. Once again, the impact of both countries was roughly the same, although the United States is slightly larger in its effect. In 1931, once again about 11 percent of the world's gold stock is unused, but this time the contribution is different; the United States has eased its policy whereas France accounts for about 80 percent of the excess. (Recall that the United States had begun to lose gold reserves by this point, and its cover ratio had started to fall.) In 1932, France is entirely responsible for the effective withdrawal of 13 percent of the world's gold stock from circulation. By this time, however, the gold standard had begun to disintegrate, with Britain and a host of other countries allowing their currencies to depreciate in late 1931. The link between gold and prices was increasingly being severed.

In sum, U.S. and France exerted roughly equal deflationary pressure on the rest of the world in 1929 and 1930 and France exerted a much more deflationary impact in 1931 and 1932. Over the entire period from 1928 to 1932 , France had a greater deflationary impact than the 
United States: it could have released 13.7 percent of the world's gold stock, while the United States could have released 11.7 percent, and still have maintained their 1928 cover ratios.

Figure 7: Effective Reduction in World's Monetary Gold Stock, 1929-32

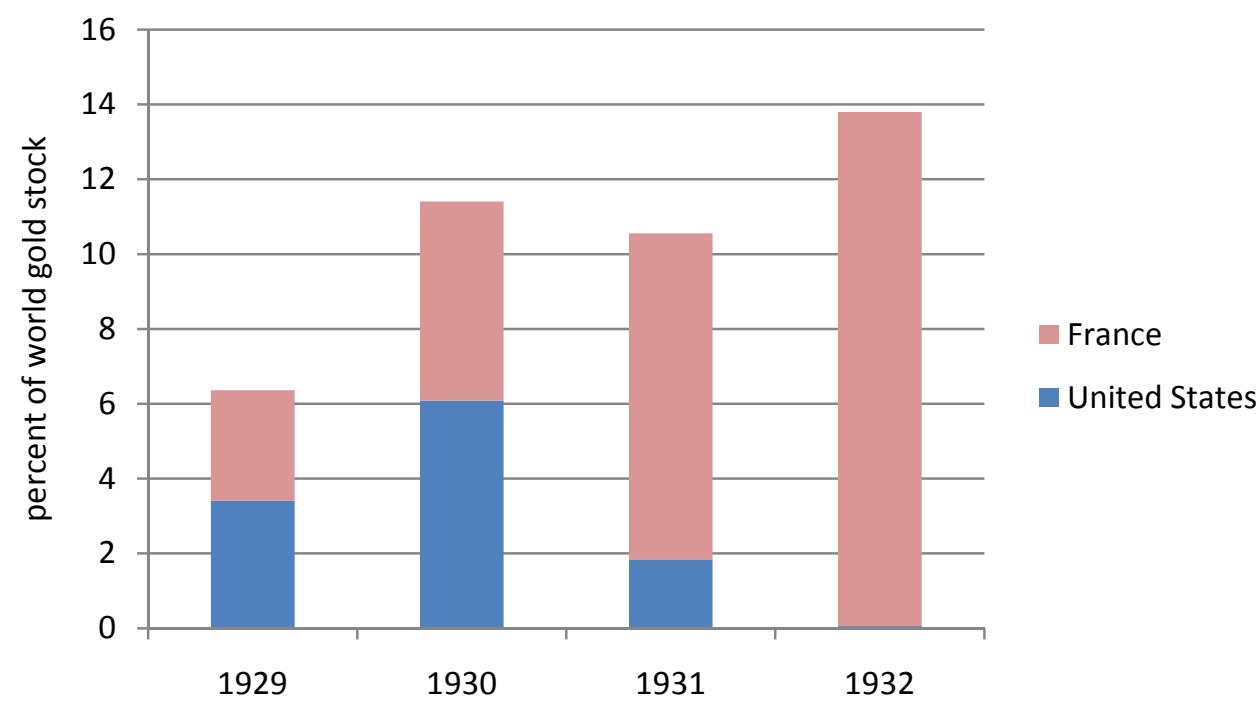

Source: see text.

In his 1752 essay “Of Money,” David Hume remarked: "If the coin be locked up in chests, it is the same thing with regard to prices, as if it were annihilated." This analogy seems to apply to the American and French accumulation of gold during this period. So what was the impact of the effective withdrawal of this gold from circulation on the world price level? For this we can refer back to the regression coefficients from Table 3 indicating a 1 percent increase in the gold stock would increase world prices by 1.5 percent. In 1929, the United States and France effectively withdrew 6 percent of the world's gold stock from circulation. This implies that world prices in 1930 should fall by 9.5 percent (6.4 X 1.5), other things being equal. In that 
year, world prices actually fell 17 percent. In 1930, the United States and France increased the amount of gold that they were hoarding by 5 percentage points $(11.4-6.4)$. This implies that prices in 1931 should fall 7.6 percent ( 5 X 1.5), while in fact they fell 15.5 percent. In 1931, there was an easing of this situation due to U.S. gold losses and a reduction in its cover ratio, but France made up for this by accumulating and sterilizing more gold. By 1932 the impact on prices does not quite matter as much because many countries were off the gold standard by this point. The link between gold and prices was increasingly being severed, and France could accumulate all the gold it wanted without affecting world prices as significantly.

From this simple exercise, we can conclude that the Federal Reserve and Bank of France directly account for about half of the 30 percent deflation experienced in 1930 and 1931. Of course, once the deflationary spiral began, other factors began to reinforce it. The most important factor was that growing insolvency (due to debt-deflation problems identified by Irving Fisher) contributed to bank failures, which in turn led to a reduction in the money multiplier as the currency to deposit ratio increased (Boughton and Wicker 1979). However, these endogenous responses cannot be considered as independent of the initial deflationary impulse, and therefore U.S. and French policies can be held indirectly responsible for at least some portion of the remaining "unexplained" part of the price decline.

This calculation can be compared to Sumner (1991), whose accounting of the supply and demand for gold yields comparable results. Sumner reports that, between December 1926 and December 1932, gold supply increased 26 percent and gold demand increased 63 percent, thereby producing a 37 percent fall in world prices. Of the 63 percent increase in gold demand, 31 percentage points (49 percent) arose from France, 14 percentage points ( 22 percent) arose from the United States, and 17 percentage points (29 percent) arose from the rest of the world. 
However, this demand includes private demand (currency) as well as central bank demand. In terms of central bank demand, the Bank of France accounts for 17 percentage points of the increase in demand whereas the Federal Reserve was actually reducing its monetary demand for gold by 5 percentage points.

The findings of this paper are entirely consistent with Sumner's $(1991,388)$ conclusion that "restrictive French monetary policy can explain much of the decrease in the world price level throughout the 1926-1932 period."

\section{Conclusion}

The standard account of the onset of the Great Depression usually begins with the Federal Reserve's tightening of monetary policy in 1928. However, the rapid accumulation and effective sterilization of gold reserves by the Bank of France deserves equal - if not greater - billing in the narrative. The impact of the monetary policies of the two countries was equally significant in producing deflationary pressure in 1929 and 1930, while France became the dominant deflationary force in 1931 and 1932.

This paper provides a very simple explanation for the sudden onset of deflation in terms of changes in U.S. and French monetary policy around 1928. Of course, declining prices do not necessarily imply declining output, yet recent research has shown that the Great Depression of the 1930s is somewhat unique in linking the two (Atkeson and Kehoe 2004, Bordo, Lane, and Redish 2004). Hence, simply avoiding deflation during this period would likely have changed the course of world history. One shudders to think of the historical ramifications of the policies pursued at this time. As Robert Mundell $(2000,331)$ has speculated: "Had the price of gold been raised in the late 1920's, or, alternatively, had the major central banks pursued policies of 
price stability instead of adhering to the gold standard, there would have been no Great Depression, no Nazi revolution, and no World War II." 


\section{Appendix: Contemporary Analysis of the French Gold Situation}

This paper has focused on the American and French sterilization of gold in the late 1920s and its deflationary consequences. Several leading economists of the period, particularly Gustav Cassel and John Maynard Keynes, were well aware of the situation and warned of its adverse consequences. This appendix provides a brief summary of contemporary views on the French gold situation.

The text noted that Cassel warned of an impending shortage of gold and the possibility of worldwide price deflation after World War I. He continued to emphasize this thinking throughout the 1920s. In his May 1928 lectures at Columbia University, Cassel $(1928,44)$ argued that "the great problem before us is how to meet the growing scarcity of gold which threatens the world both from increased demand and from diminished supply." While little could be done about the projected slowing growth in the supply of gold, Cassel proposed to remedy the imbalance by restricting the monetary demand for gold: "only if we succeed in doing this can we hope to prevent a permanent fall of the general price level and a prolonged and worldwide depression which would inevitably be connected with such a fall in prices."

Cassel's fears about an insufficient supply of gold were misplaced: as we have seen, the supply of monetary gold continued to expand through the early 1930s. There was no shortage of gold supplies in the late 1920s and early 1930s, but his fears about the increasing monetary demand for gold were entirely realized.

The increase in central bank demand for gold was soon evident. In January 1929, Allyn Young (1929) decried the hoarding of gold by central banks, saying that it was "an expression of financial nationalism" and was "inexplicable on any rationale grounds." He stated that "there is 
plenty of gold" and that "production and trade can grow without there being a general fall in prices, if only the central banks of the world will permit it." Young concluded:

"No thinking person wants another period of inflation. But the high-gold-reserve-ratio fetish ought not to have the influence which it now has upon banking policies. A gradual downward trend of prices is probable, not because the supply of gold is or will soon become inadequate, but merely because the central banks of different countries will probably try to maintain their separate hoards of gold."

That same month (January 1929), John Maynard Keynes acknowledged that he had been wrong not to take Cassel's pronouncements more seriously. Keynes (1929) warned that "a difficult, and even a dangerous, situation is developing" because "there may not be enough gold in the world to allow all the central banks to feel comfortable at the same time. In this event they will compete to get what gold there is which means that each will force his neighbor to tighten credit in self-protection, and that a protracted deflation will restrict the world's economic activity, until, at long last, the working classes of every country have been driven down against their impassioned resistance to a lower money wage."

The recent behavior of the Bank of France "cannot help but cause an artificial shortage of gold," he noted. "We all survive, and the Bank of England in particular, by favour of the Bank of France. ... The question of the sufficiency of the world's gold supplies in the abundance or scarcity of credit in the world's business lies, therefore, for the near future in the hands of the Bank of France."

By mid-1929, world wholesale prices began to fall and the deflationary spiral had begun. In March 1930 testimony before the Macmillan Committee, Keynes argued that the situation was 
reversible: "If . . . the United States and France were to declare that they would do everything reasonably in their power not to take more gold for a year or two, and, if practicable to lose ten percent of their present holdings, one would say that, in addition to other expedients, would make the position almost safe. I am absolutely confident that we could bring back the level of prices to what it was a couple of years ago." However, the problem was that "it is very doubtful how far the Bank of France is aware either of the existence of the problem or of the nature of the solution” (JMK 20, 154). The Macmillan Report, largely written by Keynes, called for a coordinated reducing in central bank discount rates and the simultaneous reduction in reserve requirements (cover ratios) so that a larger credit structure could be built on the existing reserve base.

British officials at the League of Nations also tried to raise the issue, but it was so controversial that the multilateral body was unable to address it head on (Clavin and Wessels 2004). The Gold Delegation issued an interim report in September 1930 that largely sidestepped the main policy issues. However, it did conclude that "the problem of the distribution of gold is thus one of great importance ... if the distribution of gold is the result of excessive or abnormal competition by a few countries, or if it has the effect of sterilizing important amounts of monetary stocks, serious consequences will arise affecting the general level of prices" (League of Nations 1930, 17). It noted that the amount of gold cover against notes and sight liabilities is determined by many factors, but that minimum reserves were usually established by national legislation. While no one country could act to reduce its cover ratio, the Delegation suggested that international agreement to reduce cover ratios could alleviate the problem of demand for monetary gold. 
In the fall of 1930, Cassel observed that "recent times have been characterized by a relentless struggle for gold rather than by that conscious collaboration, aiming at a limitation of demands, which would have been necessary to stabilize the purchasing power of gold." Cassel stated bluntly what the more diplomatic League of Nations report could not say: that it was "especially remarkable that the Bank of France has consistently and unnecessarily acquired enormous amounts of gold without troubling in the least about the consequences that such a procedure is bound to have on the rest of the world" (Howe 1934, 65).

In September 1931, after Britain faced mounting losses in gold reserves as a result of the European financial crisis in mid-1931, Keynes argued that the United States and France were "primarily responsible for the disastrous fall in the level of world prices."

"The whole world is heartily sick of the selfishness and folly with which the international gold standard is being worked. Instead of being a means of facilitating international trade, the gold standard has become a curse laid upon the economic life of the world. It is not necessary to go into academic questions as to how far the fall in the world level of prices has been brought about by a worldwide shortage of gold. It is only necessary to look at the present distribution of the world's gold stocks" (JMK 20, 600).

Keynes called for an international gold conference to address the issue:

"This gold conference has to be put forward to America and France as an act of common sense and prudence, as a means of saving the economic world from the disaster which will surely overtake it if the slump is to be prolonged by a universal deflation policy.... We must make it plain to our friends on the gold standard that, if they refuse to play the game according to the rules, this is not to be made a compelling reason for reducing the standard of life in this country for a generation. If, as a result of the conference's failure, 
we were to leave the gold standard system, this would be preferable to the deflation policy with which the Coalition Government intends to launch this country in the race for economic suicide" (JMK 20, 602-3).

In fact, time had run out and Britain left the gold standard just days after Keynes wrote this piece. Keynes $(1932,78,82-83)$ called Britain's ending of the gold standard a "most blessed event" and said that "the undermining of the competitive position of the export industries of these gold countries will be, in truth, in response to their own request; or, at any rate, a case of poetic justice"

In lectures at Oxford in 1932, Cassel looked back on the preceding few years and blamed the sterilization of gold by the United States and France for the economic disaster. "The fact that the gold-receiving countries failed to use their increasing gold reserves for extending the effective supply of means of payment must be regarded as abnormal and, therefore, as an independent cause of the fall in prices at the side of the maldistribution of gold," Cassel (1928, 70-1) argued. "The breakdown of the Gold Standard was the result of a flagrant mismanagement of this monetary mechanism.” He rejected the excuses given by French and American authorities for their failure to monetize the gold inflows: "The fact that France and the United States have drawn disproportionate quantities of gold to themselves is certainly very disquieting, but the defense that is offered for this behavior is still more appalling."

Cassel $(1932,75)$ was not optimistic that there would be any change in French policy: "the great gold accumulation in France is looked upon with so much national satisfaction and pride and, in addition, has actually been used for the exercise of so much political power, that one cannot but get the impression that France will not readily consent to a reduction of her gold 
holdings, still less do anything in order positively to further a better international distribution of gold."

Ralph Hawtrey $(1932,38)$ also reflected back on this period: "I am inclined therefore to say that while the French absorption of gold in the period from January 1929 to May 1931 was in fact one of the most powerful causes of the world depression, that is only because it was allowed to react to an unnecessary degree upon the monetary policy of other countries."

In the United States, George Warren and Frank Pearson $(1933,125)$ were pushing a similar line about the problems with the gold standard: "The present depression is not an act of God for the purification of men's souls. It is not a business cycle. It is not due to extravagant living. It is not due to unsound business practices. It is not due to too great efficiency. It is not due to lack of confidence, but is the cause of lack of confidence. It is due to high demand for gold following a period of low demand for gold. It teaches the devastating effects of deflation, but teaches no other lesson that is good for society." 


\section{References}

Accominotti, Olivier. 2009. "The Sterling Trap: Foreign Reserves Management at the Bank of France, 1928-1936.” European Review of Economic History 13, 349-376.

Atkeson, Andrew, and Patrick J. Kehoe. 2004. "Deflation and Depression: Is there an Empirical Link?” American Economic Review 94, 99-103.

Bernanke, Ben. 1995. "The Macroeconomics of the Great Depression: A Comparative Approach." Journal of Money, Credit and Banking 27, 1-28.

Bernanke, Ben, and Ilian Mihov. 2000. "Deflation and Monetary Contraction in the Great Depression: An Analysis by Simple Ratios." In Ben Bernanke, Essays on the Great Depression. Princeton: Princeton University Press.

Board of Governors of the Federal Reserve System. 1943. Banking and Monetary Statistics. Washington, D.C.: Board of Governors of the F

Bordo, Michael D., John Landon Lane, and Angela Redish. 2004. "Good versus Bad Deflation: Lessons from the Gold Standard Era." NBER Working Paper No. 10329.

Boughton, James M., and Elmus R. Wicker. 1979. "The Behavior of the Currency-Deposit Ratio during the Great Depression." Journal of Money, Credit and Banking 11, 405-418.

Cassel, Gustav. 1928. Postwar Monetary Stabilization. New York: Columbia University Press.

Cassel, Gustav. 1932. “Memorandum of Dissent.” In League of Nations (1932).

Cassel, Gustav. 1932. The Crisis in the World's Monetary System. Oxford: Clarendon Press.

Choudhri, Ehsan, and Levis Kochin. 1980. "The Exchange Rate and the International Transmission of Business Cycle Disturbances: Some Evidence from the Great Depression." Journal of Money, Credit, and Banking 12, 565-74.

Clavin, Patricia, and Jens-Wilhelm Wessels. 2004. "Another Golden Idol? The League of Nations' Gold Delegation and the Great Depression, 1929-32.” International History Review 26, 765-795.

Eichengreen, Barry. 1986. "The Bank of France and the Sterilization of Gold, 1926-1932." Explorations in Economic History 23, 56-84.

Eichengreen, Barry. 1990. "The Gold Exchange Standard and the Great Depression." In Elusive Stability: Essays in the History of International Finance, 1919-1939. New York: Cambridge University Press.

Eichengreen, Barry. 1992. Golden Fetters: The Gold Standard and the Great Depression, 1919- 
1939. New York: Oxford University Press.

Eichengreen, Barry, and Jeffrey Sachs. 1985. "Exchange Rates and Economic Recovery in the 1930s." Journal of Economic History 45, 925-46.

Einzig, Paul. 1931. Behind the Scenes in International Finance. London: Macmillan.

Evans, Martin, and Paul Wachtel. 1993. "Were Price Changes during the Great Depression Anticipated? Evidence from Nominal Interest Rates.” Journal of Monetary Economics 32, 3-34.

Friedman, Milton. 1991. "Forward" to Émile Moreau, The Golden Franc: Memoirs of a Governor of the Bank of France: The Stabilization of the Franc (1926-1928), trans. Stephen D. Stoller and Trevor C. Roberts. Boulder, CO: Westview Press.

Hardy, Charles O. 1936. Is There Enough Gold? Washington, D.C.: Brookings Institution Hamilton, James. 1987. "Monetary Factors in the Great Depression." Journal of Monetary Economics 19, 145-169.

Hamilton, James. 1992. "Was the Deflation During the Great Depression Anticipated? Evidence from the Commodity Futures Markets." American Economic Review 82, 157-178.

Hawtrey, Ralph. 1932. The Art of Central Banking. London: Longman, Green.

Howe, Quincy. 1934. World Diary: 1929-1934. New York: McBride.

Johnson, H. Clark. 1997. Gold, France, and the Great Depression, 1919-1932. New Haven: Yale University Press.

Keynes, John Maynard. 1929. "Is There Enough Gold? The League of Nations Inquiry.” The Nation and Athenaeum, 19 January. In Collected Works of John Maynard Keynes, 19, 775-780.

Keynes, John Maynard. 1932. In The World's Economic Crisis and the Way of Escape. London: George Allen \& Unwin.

Kitchen, Joseph. 1930. "Production and Consumption of Gold, Past and Prospective." In League of Nations (1930).

League of Nations. 1930. Interim Report on the Gold Delegation of the Financial Committee. Geneva: League of Nations.

League of Nations. 1932. Report of the Gold Delegation of the Financial Committee. Geneva: League of Nations.

Mitchell, Brian R. 1988. British Historical Statistics. New York: Cambridge University Press. 
Moggridge, Donald E. 1969. The Return to Gold, 1925: The Formuation of Economic Policy and its Critics. Cambridge: Cambridge University Press.

Mouré, Kenneth. 1991. Managing the Franc Poincaré: Economic Understanding and Political Constraint in French Monetary Policy, 1928-1936. New York: Cambridge University Press.

Mouré, Kenneth. 2002. The Gold Standard Illusion: France, the Bank of France, and the International Gold Standard, 1914-1939. New York: Oxford University Press.

Mundell, Robert A. 2000. "A Reconsideration of the Twentieth Century." American Economic Review 90, 327-340.

Patat, Jean-Pierre, and Michel Lutfalla. 1990. A Monetary History of France in the Twentieth Century. New York: St. Martin's.

Reynaud, Paul. 1933. "France and Gold.” Foreign Affairs 11, 253-267.

Rist, Charles. 1932. "The International Consequences of the Present Distribution of Gold Holdings." In Royal Institute for International Affairs, The International Gold Problem. Oxford: Oxford University Press.

Rockoff, Hugh. 1984. "Some Evidence on the Real Price of Gold, Its Costs of Production, and Commodity Prices." In A Retrospective on the Classical Gold Standard, 1821-1931, edited by Michael Bordo and Anna Schwartz. Chicago: University of Chicago Press.

Sicsic, Pierre. 1992. "Was the Franc Poincaré Deliberately Undervalued?” Explorations in Economic History 29, 69-92.

Sicsic, Pierre. 1993. "The Inflow of Gold to France from 1928 to 1934." Notes d'Études et de Recherche, Bank of France, No. 22.

Sumner, Scott. 1991. "The Equilibrium Approach to Discretionary Monetary Policy under an International Gold Standard, 1926-1932." The Manchester School of Economic \& Social Studies 59, 378-94.

Temin, Peter. Lessons from the Great Depression. Cambridge: MIT Press, 1989.

Young, Allyn A. 1929. "Downward Price Trend Probable, Due to Hoarding Gold by Central Banks.” The Annalist, January 18, 96-97. 